\title{
PENGARUH MODEL PEMBELAJARAN CORE (CONNECTING, ORGANIZING, REFLECTING AND EXTENDING) TERHADAP HASIL BELAJAR SISWA KELAS X
}

\author{
Andi Trisnowali MS ${ }^{1}$, Andi Aswina ${ }^{2}$ \\ anditrisnowali@gmail.com ${ }^{1}$ \\ Pendidikan Matematika STKIP Muhammadiyah Bone, Jl. Abu Dg Pasolong Bone B, $^{1,2}$
}

\begin{abstract}
This study aims at determining the influence of the CORE (Connecting, Organizing, Reflecting, and Extending) Learning model on the students'mathematics learning outcomes at grade X SMA 5 Watampone. The research design used was posttest only control design (posttest subjects only control group design). This research was conducted at SMA 5 Watampone. The population was all students at class $X$ and the samples were randomly selected; students at XII-2 and XII-3 classes. Data on learning outcomes obtained through posttest. Data is processed using the t-test. The results of data analysis indicated that the experimental class obtained an average value of learning outcomes (mean) is 85.28, the standard deviation (standard deviation) is 9.110, the variance is 82.993 and the standard error is 1.692, while in the control class the mean is 75.66, standard deviation 8,703, variance 75,734, and standard error mean 1,616. It is concluded that "there is influence of the CORE Learning model on the students'mathematics learning outcomes at grade X SMA 5 Watampone.
\end{abstract}

Keywords: CORE Learning Models, Mathematics Learning Outcomes

Diterima: 13-07-2019, Direview: 15-07-2019, Diterbitkan: 15-08-2019

\section{PENDAHULUAN}

Mata pelajaran matematika perlu diberikan kepada semua siswa mulai dari sekolah dasar agar siswa dapat dibekali kemampuan berfikir logis, analitis, sistematis, kritis dan kreatif serta kemampuan bekerja sama. Kompetensi tersebut diperlukan siswa agar dapat memperoleh, mengelolah dan memanfaatkan informasi untuk bertahan hidup pada keadaan zaman yang selalu berkembang. Oleh karena itu dalam proses belajar diperlukan 
pembelajaran yang efektif. ada berbagai faktor yang dapat mempengaruhi keberhasilan siswa adalah faktor internal dan eksternal. Faktor ekstrnal yaitu faktor yang berasal dari luar diri siswa misalnya keluarga dan lingkungan. Faktor internal meliputi bakat, minat dan perhatian. Faktor yang ikut mempengaruhi hasil belajar siswa khususnya dalam mata pelajaran matematika adalah faktor psikologis (internal), masih banyak siswa yang menganggap bahwa matematika merupakan ilmu yang sulit dipelajari. Untuk mengatasi masalah tersebut diatas, maka cara yang paling efektif adalah dengan melaksanakan proses pembelajaran dengan menggunakan model pembelajaran yang bisa menarik minat dan mengaktifkan siswa. Menurut Suyatno kegiatan belajar menggunakan model pembelajaran CORE memiliki pengaruh yang positif diantaranya terjadi Peningkatan pada siswa setelah belajar yaitu siswa aktif dalam belajar, melatih daya ingat siswa tentang suatu konsep atau informasi, melatih daya pikir siswa terhadap suatu masalah, dan memberikan pengalaman belajar inovatif kepada siswa (Muizaddin \& Budi, 2016:240).

Untuk mewujudkan hal tersebut pemerintah telah melakukan perubahan pada kurikulum yaitu ditetapkannya kurikulum 2013 (K13) sebagai pengganti dari kurikulum 2006 untuk dipakai disekolah-sekolah karena Kurikulum 2013 dipercaya dapat menjadikan siswa lebih aktif dalam proses pembelajaran. Dikarenakan kurikulum 2013 lebih berfokus pada siswa. Melihat kondisi yang terjadi pada siswa kelas X SMA Negeri 5 Watampone sesuai dengan hasil observasi awal peneliti, yang telah menggunakan kurikulum 2013 nyatanya tak terlalu banyak berpengaruh terhadap hasil belajar siswa dalam mata pelajaran matematika. Hal ini dibuktikan dari data hasil belajar siswa yang hanya $40 \%$ dari 180 siswa kelas X mencapai nilai standar KKM pelajaran matematika (75) yang ditetapkan disekolah.

Berdasarkan kondisi tersebut peneliti ingin mencoba mengatasi permasalahan tersebut dengan melakukan penerapan model pembelajaran CORE (Connecting, Organizing, Reflecting dan Extending). Model pembelajaran CORE (connecting, organizing, reflecting, extending) adalah model pembelajaran yang menekankan kemampuan berpikir siswa untuk menghubungkan, mengorganisasikan, mendalami, mengelola, dan mengembangkan informasi yang didapat. Kegiatan menghubungkan konsep/informasi lama dengan konsep/informasi baru siswa dilatih untuk mengingat konsep/informasi lama dan menggunakan konsep/informasi lama untuk digunakan dalam konsep/informasi baru. Kegiatan mengorganisasikan ide-ide siswa dilatih untuk mengorganisaikan, mengelola informasi yang sudah didapat. Kegiatan refleksi merupakan kegiatan memperdalam, menggali informasi untuk memperkuat konsep yang telah dimiliki. Kegiatan 
mengembangkan informasi siswa dilatih mengembangkan, memperluas informasi yang sudah didapat dan menggunakannya untuk menemukan konsep dan informasi baru. Peneliti memilih model pembelajaran CORE karena menganggap model pembelajaran ini merupakan model pembelajaran yang memadukan antara kurikulum 2006 dan kurikulum 2013 karena model pembelajaran ini tidak hanya membuat siswa lebih aktif tapi guru juga aktif dalam proses pembelajaran. Dengan adanya model pembelajaran CORE (Connecting, Organizing, Reflecting and Extending) sebagai komponen yang mampu berpengaruh dalam pencapaian tujuan pembelajaran dan berperan aktif membuat siswa terlibat aktif dan berfikir lebih dalam memecahkan masalah matematika. Model pembelajaran CORE Connecting, Organizing, Reflecting and Extending) juga diharapkan dapat membuat siswa termotivasi dan meningkatkan minat dalam pembelajaran matematika sehingga hasil belajarnya pun bias mengalami peningkatan.

Berdasarkan hal tersebut, perlu dilakukan penelitian untuk mengetahui apakah model pembelajaran CORE (Connecting, Organizing, Reflecting and Extending) berpengaruh terhadap hasil belajar siswa, sehingga peneliti perlu melakukan penelitian yang berjudul "Pengaruh Model Pembelajaran CORE (Connecting, Organizing, Reflecting, dan Extending) terhadap hasil belajar siswa kelas X SMA Negeri 5 Watampone".

Berdasarkan latar belakang yang telah diuraikan, maka rumusan masalah penelitian ini yaitu :

1. Apakah model pembelajaran CORE (Connecting, Organizing, Reflecting dan Extending) berpengaruh terhadap hasil belajar siswa kelas X SMA Negeri 5 Watampone?

2. Bagaimanakah keaktifan siswa kelas X SMA Negeri 5 Watampone dalam mengikuti pembelajaran?

3. Bagaimanakah keterlaksanaan model pembelajaran CORE (Connecting, Organizing, Reflecting dan Extending) pada siswa kelas X SMA Negeri 5 Watampone ?

\section{METODE}

\section{Jenis Penelitian}

Jenis penelitian yang di gunakan merupakan penelitian eksperimen. Variabel bebas yang dimaksud dalam penelitian ini yaitu model pembelajaran CORE (connecting, 
organizing, reflecting, extending. Adapun variabel terikat dalam penelitian ini yaitu hasil belajar.

\section{Populasi dan Sampel}

Populasi penelitian ini tidak memiliki kelas unggulan sehingga kemampuan akedemik relatif sama. Populasi dalam penelitian ini adalah siswa kelas X SMA Negeri 5 Watampone tahun ajaran 2018/2019 berjumlah 198 siswa.

\section{Desain Penelitian}

Desain penelitian eksperimen yang digunakan yaitu Posttest-Only Control Design. Pada desain penelitian ini terdapat dua kelompok yang dipilih secara acak. Kelompok pertama memperoleh perlakuan berupa model pembelajaran CORE sebagai kelas eksperimen, dan kelas kedua tidak memperoleh perlakuan khusus atau perlakuan biasa sebagai kelompok kontrol. Desain tersebut dapat dijelaskan pada Tabel 3.5 sebagai berikut :

Tabel 1. Desain Penelitian Posttest-Only Control Design

\begin{tabular}{ccc}
\hline Kelompok & Perlakuan & Posttest \\
\hline$(\mathrm{R})$ Eksperimen & $\mathrm{X}_{1}$ & $\mathrm{Y}$ \\
\hline (R) Kontrol & $\mathrm{X}_{2}$ & $\mathrm{Y}$ \\
\hline & \multicolumn{2}{c}{ Sumber: Rahmadiyah $(2015$}
\end{tabular}

Sumber: Rahmadiyah (2015: 25)

Keterangan:

$\mathrm{R}=$ Pemilihan kelas secara acak

$\mathrm{X}_{1}=$ Perlakuan yang diberikan menggunakan model pembelajaran CORE

$\mathrm{X}_{2}=$ Perlakuan dengan peebelajaran konvensional

$\mathrm{Y}=$ Hasil Posttest

\section{Instrumen Penelitian}

Dalam penelitian ini, instrumen penelitian yang digunakan oleh peneliti adalah tes, lembar aktivitas siswa, dan lembar observasi.

Tes adalah serentetan pertanyaan atau latihan serta alat lain yang digunakan untuk mengukur keterampilan, pengetahuan intelegensi, kemampuan atau bakat yang dimiliki oleh individu atau kelompok Arikunto (2010: 193). Tes yang dimaksudkan disini ialah tes hasil belajar. Tes Hasil Belajar sebagai instrumen pengumpul data adalah serangkaian pertanyaan atau latihan yang digunakan untuk mengukur keterampilan, pengetahuan, intelegensi, 
kemampuan, atau bakat yang dimiliki oleh individu atau kelompok Metode tes dalam penelitian ini berupa tes essay sebanyak 10 butir nomor soal sesuai dengan materi yang diajukan. Penilaian ini akan diambil dari tes yang diberikan setelah diberikan perlakuan (posttest). Hasil pengolahan data ini digunakan untuk menguji kebenaran hipotesis penelitian.

Aktivitas siswa merupakan kegiatan atau perilaku yang terjadi selama proses belajar mengajar baik itu kegiatan fisik hingga kegiatan psikis. Lembar aktivitas siswa digunakan untuk mengukur aktivitas siswa, karena aktivitas dalam mengikuti proses belajar mengajar sangat menentukan hasil belajar siswa. Penilaian aktivitas siswa dilakukan dengan cara mengisi lembaran yang berisi seperangkat pertanyaan. Berdasarkan dari data yang didapatkan akan dilakukan pembandingan bagaiman pengaruh antara siswa yang aktif dan tidak aktif terhadap hasil belajarnya.

Lembar observasi merupakan lembar penilaian yang dilakukan untuk menilai keterlaksanaan model pembelajaran yang diterapkan pada saat proses pembelajaran berlangsung. Keterlaksanaan model pembelajaran juga mempunyai pengaruh terhadap hasil belajar siswa. Lembar observasi keterlaksanaan dilakukan oleh tim observer dengan cara mengisi lembaran berisi langkah-langkah dari model pembelajaran. Penilaian ini dilakukan pada saat pembelajaran berlangsung.

\section{Teknik Analisis Data}

Adapun teknik analisis data yang digunakan penelitian ini adalah teknik analisis statistik deskriptif dan analisis statistik inferensial.

\section{Analisis Statistik Inferensial}

Data yang diperoleh merupakan data kuantitatif yakni mengenai hasil belajar siswa yang berbentuk interval/rasio. Pengujian hipotesis ini menggunakan uji dua pihak dimana uji-t dilakukan dengan berangkat dari data yang berdistribusi normal. Uji hipotesisnya adalah uji perbedaan dua rata-rata yang digunakan untuk mengetahui ada tidaknya perbedaan antara kelas eksperimen dan kelas kontrol setelah diberi perlakuan. Sebelum uji hipotesis terlebih dahulu dilakukan uji persyaratan:

Uji homogenitas dimaksudkan untuk mengetahui apakah kelompok sampel memiliki varians yang sama atau tidak, selanjutnya Uji Normalitas untuk mengetahui apakah sampel yang diteliti berasal dari populasi berdistribusi normal atau tidak setelah itu Uji Hipotesis 
data yang diperoleh merupakan data kuantitatif yakni mengenai hasil belajar siswa yang berbentuk interval atau rasio.

\section{Analisis Statistik Deskriptif}

Analisis statistik deskriptif digunakan untuk mendeskripsikan atau menggambarkan karakteristik responden penelitian setiap variabel, yaitu rata-rata, skor terendah dan tertinggi, persentase dan standar deviasi.

a) Analisis hasil belajar

Untuk mendeskripsikan atau menggambarkan hasil belajar siswa maka akan dilakukan pengekategorian sebagai berikut.

Tabel 2. Kategori Hasil Belajar Siswa

\begin{tabular}{cc}
\hline Interval Skor & Kategori \\
\hline $0-34$ & Sangat rendah \\
$35-54$ & Rendah \\
$55-64$ & Sedang \\
$65-84$ & Tinggi \\
$85-100$ & Sangat Tinggi \\
\hline
\end{tabular}

Sumber:(Purwanto, 2009:30)

b) Analisis keaktifan siswa

Salah satu faktor yang mempengaruhi hasil belajar siswa yaitu keaktifan siswa dalam mengikuti pembelajaran sehingga peneliti menggunakan pengkategorian sebagai berikut:

Tabel 3. Kategori Keaktifan Siswa

\begin{tabular}{cc}
\hline Interval Skor & Kategori \\
\hline $0 \%-20 \%$ & Sangat kurang Aktif \\
$21 \%-40 \%$ & Kurang Aktif \\
$41 \%-60 \%$ & Sedang \\
$61 \%-80 \%$ & Aktif \\
$81 \%-100 \%$ & Sangat Aktif \\
\hline
\end{tabular}

Sumber: Faiq (2013)

c) Analisis keterlaksanaan Model pembelajaran

Teknik analisis data terhadap keterlaksanaan model pembelajaran digunakan untuk memperkuat penilaian terhadap hasil belajar yang akan diperoleh. tingkat kemampuan guru dalam melaksanakan model pembelajaran dihitung dengan cara menjumlah skor yang diperoleh kemudian membaginya dengan jumlah skor maksimal lalu mengalikan dengan 100. 


$$
\text { Nilai }=\frac{\text { skor perolehan }}{\text { skor maksimal }} \times 100
$$

Adapun pengkategorian keterlaksanaan dalam mengelola pembelajaran digunakan kategori pada tabel berikut.

Tabel 4. Kategori Keterlaksanaan Model Pembelajaran

\begin{tabular}{ccc}
\hline & Interval Skor & Kategori \\
\hline 1 & $\leq \quad 32$ & Tidak terlaksana \\
2 & $33-49$ & Kurang terlaksana \\
3 & $50-66$ & Cukup terlaksana \\
4 & $67-83$ & Terlaksana dengan baik \\
5 & $84-100$ & Terlaksanan dengan sangat baik \\
\hline
\end{tabular}

Sumber: Karmila (2016: 41)

\section{HASIL PENELITIAN DAN PEMBAHASAN}

Data yang diperoleh merupakan data yang berbentuk interval/rasio yaitu mengenai data hasil belajar siswa yang diperoleh langsung setelah pemberian instrumen berupa posttest dikedua kelas yang dijadikan sampel. Berikut ini data perhitungan statistik hasil belajar matematika siswa kelas kontrol dan kelas eksperimen menggunakan alat bantu SPSS 23.0 .

Tabel 5. Statistik nilai hasil belajar siswa

Statistics

\begin{tabular}{|c|c|c|}
\hline & $\begin{array}{c}\text { Kelas } \\
\text { Eksperimen }\end{array}$ & $\begin{array}{c}\text { Kelas } \\
\text { Kontrol }\end{array}$ \\
\hline Valid & 29 & 29 \\
\hline Missing & 0 & 0 \\
\hline Mean & 85,28 & 75,66 \\
\hline Std. Error of & 1,692 & 1,616 \\
\hline Mean & 85,00 & 75,00 \\
\hline Median & 82 & 70 \\
\hline Mode & 9,110 & 8,703 \\
\hline Std. Deviation & 82,99 & 75,734 \\
\hline Variance & 3 & 55 \\
\hline Minimum & 65 & 90 \\
\hline Maximum & 100 & 2194 \\
\hline Sum & 2473 & \\
\hline
\end{tabular}


Data pada tabel 5 merupakan hasil perhitungan statistik untuk kelas kontrol memiliki nilai rata-rata (mean) 75,66, nilai standar eror mean 1,616 , median 75 , modus 70 , nilai standar deviasinya 8,703 , variansnya 75,734 , nilai minimumnya 55 dan nilai maksimumnya 90. Sedangkan untuk kelas eksperimen memiliki nilai rata-rata (mean) 85,28, nilai standar eror mean 1,692 , median 85 , modus 82 , nilai standar deviasinya 9,110, variansnya 82,993, nilai minimumnya 65 dan nilai maksimumnya 100.

Analisis statistik inferensial pada tahap ini digunakan untuk menganalisis data posttest yang diperoleh setelah diberi perlakuan. data hasil belajar siswa dianalisis dengan menggunakan uji homogenitas, uji normalitas dan uji hipotesis.

1) Uji Homogenitas

Uji Homogenitas digunakan untuk mengetahui apakah data tersebut mempunyai varians yang sama (homogen) atau tidak. Dalam penelitian ini,uji homogenitas menggunakan uji Levene dengan alat bantu program SPSS 23.0

Tabel 6. Output Uji Homogenitas posttest kelas Eksperimen

\begin{tabular}{cccc}
\hline $\begin{array}{c}\text { Levene } \\
\text { Statistic }\end{array}$ & df1 & df2 & Sig. \\
\hline 2,259 & 6 & 18 &, 084 \\
\hline
\end{tabular}

Pada output diatas diperoleh nilai signifikasi $=0,084>0,05$, sehingga artinya data posttest kelas Eksperimen tersebut homogen.

Tabel 7. Output Uji Homogenitas Posttest kelas Kontrol

\begin{tabular}{crrr}
\hline $\begin{array}{c}\text { Levene } \\
\text { Statistic }\end{array}$ & df1 & df2 & Sig. \\
\hline 2,385 & 9 & 16 &, 062 \\
\hline
\end{tabular}

Pada output diatas diperoleh nilai signifikasi $=0,062>0,05$, sehingga artinya data posttest kelas Kontrol tersebut homogen.

2) Uji Normalitas

Uji normalitas digunakan untuk mengetahui apakah data berdistribusi normal atau tidak. Pengujian normalitas data dalam penelitian ini menggunakan uji KolmogorovSmirnov dengan alat bantu SPSS 23.0. 
Tabel 8. Output uji Normalitas Nilai Posttest

\begin{tabular}{lrrr}
\hline & \multicolumn{3}{c}{ Kolmogorov-Smirnov } \\
\hline & Statistic & df & Sig. \\
\hline Kelas &, 123 & 29 &, $200^{*}$ \\
Eksperiment &, 146 & 29 &, 119 \\
Kelas Kontrol & & & \\
\hline
\end{tabular}

Pada output diatas diperoleh nilai signifikasi kelas Eksperimen $=0,200>0,05$, sehingga artinya data posttest kelas Eksperimen tersebut Normal. Dan untuk nilai signifikasi kelas Kontrol $=0,119>0,05$, sehingga artinya data posttest kelas Kontrol tersebut Normal Perhitungan.

3) Uji-t (uji hipotesis)

Setelah melakukan uji homogenitas dan uji normalitas menggunakan SPSS versi 23.0 selanjutnya dilakukan uji hipotesis (uji-t) menggunakan independent samples T test yang juga menggunakan alat bantu SPSS versi 23.0

Tabel 9. Output Uji hipotesis (uji t)

\begin{tabular}{cccr}
\hline & $\mathrm{t}$ & $\mathrm{df}$ & \multicolumn{1}{c}{ Sig. (2-tailed) } \\
\hline $\begin{array}{c}\text { Hasil Belajar } \\
\text { Matematika }\end{array}$ & 4,112 & 56 &, 000 \\
\hline
\end{tabular}

Berdasarkan tabel 9, dapat dilihat hasil pengujian dengan uji-t diperoleh nilai signifikansi 0,000 dan t hitung 4,112. Nilai signifikan yang diperoleh lebih kecil dari nilai signifikansi uji yaitu 0,05 yakni $0,000<0,05$ dan nilai t hitung lebih besar dari t tabel yaitu 1,67 yakni 4,112 > 1,67. Hal ini berarti $\mathrm{H}_{0}$ ditolak dan $\mathrm{H}_{1}$ diterima, sehingga dapat disimpulkan bahwa ada pengaruh model pembelajaran CORE (connecting, Organizing, Reflecting, Extending) Terhadap hasil belajar matematika siswa.

\section{PEMBAHASAN}

Dari hasil penelitian diperolah hasil bahwa terdapat pengaruh hasil belajar matematika siswa kelas $\mathrm{X}$ dengan penggunaan model pembelajaran CORE (Connecting, Organizing, Reflecting Extending). Hal tersebut terlihat pada nilai hasil belajar yang diperoleh oleh siswa pada kelas eksperimen dan kelas kontrol. Berdasarkan tabel 4.9 mengenai statistik nilai hasil belajar pada kelas eksperimen dan kelas kontrol yang telah dijabarkan pada hasil penelitian sebelumnya, diketahui bahwa nilai rata-rata (mean) yang diperoleh kelas eksperimen adalah 85,28 dengan nilai minimun 65 dan nilai maksimum 100 . 
Sedangkan nilai rata-rata (mean) kelas kontrol yang diperoleh adalah 75,66 dengan nilai minimum 55 dan nilai maksimum 90. Hal tersebut menjelaskan bahwa nilai rata-rata (mean) pada kelas eksperimen dengan penerapan model pembelajaran CORE (Connecting, Organizing, Reflecting, Extending) lebih tinggi dibandingkan kelas kontrol yang tidak menerapkan model pembelajaran CORE (Connecting, Organizing, Reflecting, Extending) dalam proses pembelajaran $(85,28>75,66)$.

Pada penilaian keaktifan siswa menggunakan lembar aktivitas siswa pada pertemuan pertama kelas kontrol terdapat 11 siswa yang aktif dan 2 siswa sangat aktif sedangkan pada kelas eksperimen terdapat 18 siswa yang aktif dan 3 siswa yang sangat aktif. Pada pertemuan kedua kelas kontrol terdapat 15 siswa yang aktif dan 3 siswa yang sangat aktif sedangkan pada kelas eksperimen 16 siswa yang aktif dan 6 siswa sangat aktif. Berdasarkan hal tersebut menunjukkan bahwa kelas eksperimen yang menerapkan model pembelajaran CORE (Connecting, Organizing, Reflecting, Extending) dalam pembelajaran menunjukkan siswa lebih aktif dibandingkan kelas kontrol tanpa penggunaan model pemebelajaran CORE (Connecting, Organizing, Reflecting, Extending). Hal tersebut sejalan dengan beberapa pendapat yang menyatakan kelebihan-kelebihan model pemebelajaran CORE (Connecting, Organizing, Reflecting, Extending) diantaranya menurut Sukmawati (2011) pembelajaran CORE dapat meningkatkan interaksi siswa dengan siswa lain maupun dengan guru sehingga siswa menjadi lebih aktif dalam mengikuti pembelajaran (Muizaddin dan Budi, 2016:240). Menurut Suyatno (2009) kegiatan belajar menggunakan model pembelajaran CORE memiliki pengaruh yang positif diantaranya terjadi Peningkatan pada siswa setelah belajar yaitu siswa aktif dalam belajar, melatih daya ingat siswa tentang suatu konsep atau informasi, melatih daya pikir siswa terhadap suatu masalah, dan memberikan pengalaman belajar inovatif kepada siswa (Muizaddin dan Budi, 2016:240)

Pada uji hipotesis dengan menggunakan independent samples $T$ test dengan alat bantu SPSS versi 23.0 diperoleh nilai signifikan $0,000<0,05$ dan thitung = 4,112 dengan df 56 maka thitung > t tabel yaitu 4,112 > 1,67. Dengan demikian $\mathrm{H}_{0}$ ditolak dan $\mathrm{H}_{1}$ diterima. Jika $\mathrm{H}_{1}$ diterima maka "Ada pengaruh model pembelajaran CORE (Connecting, Organizing, Reflecting, Extending) terhadap hasil belajar matematika siswa kelas X SMA Negeri 5 Watampone Kabupaten Bone". Hal ini sejalan dengan hasil beberapa penelitian yang berurung pada kesimpulan adanya pengaruh model pembelajaran CORE (Connecting, Organizing, Reflecting, Extending) terhadap hasil belajar siswa diantaranya penelitian yang dilalukan Hidayat pada tahun 2013, Putra dkk pada tahun 2014 (Muizaddin \& Budi, 
2016:240). Hasil penelitian yang dilakukan oleh Selamat (2016: 53) menyatakan bahwa berpengaruh terhadap hasil belajar matematika siswa kelas VII SMP Negeri 2 Awangpone Kabupaten Bone. Hasil penelitian yang dilakukan oleh Dewi, dkk (2015:5) menyatakan bahwa berpengaruh signifikan terhadap kemampuan pemecahan masalah matematika siswa kelas III Gugus Raden Ajeng Kartini Kecamatan Denpasar Barat tahun ajaran 2014/2015. Hasil penelitian yang dilakukan oleh Shomad (2014:90) menyatakan bahwa model pembelajaran CORE (connecting, organizing, reflecting, dan extending) efektif terhadap kemampuan penalaran matematis siswa kelas VII SMP Negeri 29 Semarang.

\section{KESIMPULAN}

Ada pengaruh penerapan model pembelajaran CORE (Connecting, Organizing, Reflecting, Extending) terhadap hasil belajar matematika siswa kelas SMA Negeri 5 Watampone Kabupaten Bone. Hal tersebut dapat dilihat pada hasil analisis statistik deskriptif, pada kelas eksperimen memperoleh nilai rata-rata (mean) 85,28 sedangkan pada kelas kontrol memperoleh nilai rata-rata (mean) 75,66 dan juga dapat dilihat pada hasil analisis statistik inferensial uji-t (uji hipotesis) dengan alat bantu SPSS versi 23.0 diperoleh nilai signifikan 0,000. Nilai tersebut lebih kecil dari nilai signifikan uji yaitu 0,05 yakni $0,000<0,05$ dan nilai t hitung lebih besar dari t tabel yaitu 1,67 yakni 4,112>1,67. maka hipotesis peneliti diterima. Keaktifan siswa pada kelas eksperimen lebih baik dari kelas kontrol. Hal tersebut berdasarkan hasil penelitian yang diperoleh bahwa pada pertemuan pertama di kelas kontrol terdapat 16 siswa dikategori "Sedang", 11 siswa dikategori "Aktif" dan 2 siswa dikategori "Sangat Aktif" sementara pada kelas eksperimen terdapat 8 siswa dikategori "Sedang", 18 siswa dikategori "Aktif" dan 3 siswa dikategori "Sangat Aktif". Dan pada pertemuan kedua di kelas kontrol terdapat 11 siswa di kategori "Sedang", 15 siswa dikategori "Aktif” dan 3 siswa di kategori "Sangat Aktif” sementara di kelas eksperimen terdapat 7 siswa di kategori "Sedang”, 16 siswa di kategori “Aktif” dan 6 siswa dikategori "Sangat Aktif". Model pembelajaran CORE (Connecting, Organizing, Reflecting dan Extending) terlaksana dengan baik. Hal tersebut berdasarkan hasil penilaian yang dilakukan oleh observer pada pertemuan pertama skor yang diperoleh yaitu 76,79 dan berada pada interval 67-83 dengan kategori "Terlaksana dengan baik" sementara pada pertemuan kedua skor yang diperoleh yaitu 82,14 dan berada pada interval 67-83 dengan kategori "Terlaksana dengan baik". 


\section{SARAN}

Pembelajaran dengan Model pembelajaran CORE (Connecting, Organizing, Reflecting dan Extending) dapat dipilih sebagai salah satu alternatife pembelajaran yang mendukung kemampuan dalam melaksanakan proses pembelajaran siswa, kemampuan pemecahan matematika siswa dan prestasi belajar siswa. Sehingga Kepada peneliti yang berminat pada penelitian model pembelajaran CORE untuk meningkatkan hasil belajar matematika siswa, hendaknya mengembangkan hasil penelitian ini pada bahasan yang lebih luas sehingga diperoleh hasil yang lebih maksimal agar dapat mengurangi ketergantungan pada keadaan sekitar agar siswa tersebut menjadi lebih madiri dan kepada guru matematika untuk mengingatkan siswa pentingnya melakukan pengecekan kembali dalam berbagai aspek.

\section{DAFTAR PUSTAKA}

Arikunto, S. (2006). Dasar-dasar Evaluasi Pendidikan. Jakarta: Bumi Aksara.

Arikunto, S. (2010). Prosedur Penelitian Suatu Pendekatan Praktis. Jakarta: Rineka Cipta.

Dewi, dkk. (2015). Pengaruh Penerapan Model CORE Terhadap Kemampuan Pemecahan Masalah Matematika Dengan Kovariabel Penalaran Sistematis Pada Siswa Kelas III Gugus Raden Ajeng Kartini Kecamatan Denpasar Barat. Indonesia: Universitas Pendidikan Ganesha Singaraja.

Faiq, M. (2013). lembar-observasi-aktivtas-siswa. http://penelitian tindakan kelas.blogspot.co.id/2013/02/ llembar-observasi-aktivtas-siswa. html. 14 Februari 2013. Diakses 26 Januari 2017.

Karmila. (2016). Pengaruh Model Pembelajaran Small Group Discussion Terhadap Hasil Belajar Matematika Siswa Kelas 8 SMP Negeri 1 Palakka Kabupaten Bone. Watampone : STKIP Muhammadiyah Bone.

Muizaddin, Reza, \& Sutanto, B. (2016). Model Pembelajaran CORE Sebagai Sarana Dalam Meningkatkan Hasil Belajar Siswa. Bandung: Universitas Pendidikan Indonesia.

Rahmadiyah. (2015). Pengaruh Penerapan Strategi Means-Ends Analysis (MEA) Dalam Pembelajaran Matematika Terhadap Kemampuan Berfikir kritis Matematis Siswa. Jakarta: UIN Syarif Hidayatullah

Selamat. (2016). Pengaruh Model Core Berbasis Konstektual Terhadap Kemampuan Pemahaman Matematika Siswa Kelas VII Smp Negeri 2 Awangpone Kabupaten Bone. Watampone: STKIP Muhammadiyah Bone 
Shomad, Abdush, Zahid. (2014). Keefektifan Model Pembelajaran Core Dan Pairs Check Terhadap Kemampuan Penalaran Matematis Siswa Kelas VII. Semarang: Universitas Negeri Semarang

Sugiyono. (2010). Statistika untuk Penelitian. Bandung: CV Alfabeta.

Sugiyono. (2014). Metode Penelitian Kuantitatif Kualitatif dan R\&D. Bandung: CV Alfabeta.

Sugiono. (2015). Metode Penelitian Pendidikan Pendekatan Kuantitatif, Kualitatif R\&D. Bandung: Alfabeta. 